\title{
Effect of different forage types on the volatile and sensory properties of bovine milk
}

\author{
Hope Faulkner, ${ }^{\dagger} \dagger$ Tom F. O’Callaghan, ${ }^{*}$ Stephen McAuliffe, $¥ \S$ Deirdre Hennessy,§ Catherine Stanton, ${ }^{*}$ \\ Maurice G. O’Sullivan, $\dagger$ Joseph P. Kerry, $†$ and Kieran N. Kilcawley*1 \\ *Teagasc Food Research Centre, Moorepark, Fermoy, Co. Cork, P61 C996, Ireland \\ †School of Food and Nutritional Sciences, University College Cork, T12 YT20, Ireland \\ $\ddagger$ Animal \& Grassland Research and Innovation Centre, Teagasc Moorepark, Fermoy, Co. Cork, P61 C996, Ireland \\ $\S S c h o o l$ of Biological Sciences, Queen's University, Belfast, BT17 1NN, United Kingdom
}

\begin{abstract}
The effect of 3 diets (grass, grass/clover, and total mixed ration) on the volatile and sensory properties of bovine milk was assessed over an entire lactation season. Little evidence was found of direct transfer of terpenes into raw milk from the different diets, and it is likely that the monocultures of ryegrass used with and without white clover were factors as these contained very few terpenes. Evidence of direct transfer of nonterpene volatiles from forage to the subsequent raw milks was probable; however, differences in the protein carbohydrate availability and digestion in the rumen appeared to have a greater contribution to volatile profiles. Pasteurization significantly altered the volatile profiles of all milks. A direct link between the milk fatty acid content, forage, and volatile products of lipid oxidation was also evident and differences in fatty acid content of milk due to forage may also have influenced the viscosity perception of milk. Irish sensory assessors preferred pasteurized milk produced from grass-fed cows, with least preference from milk produced from total mixed ration diets. $\beta$-Carotene content was significantly higher in milks derived from grass or grass/ clover and appears to have directly influenced color perception. Toluene and p-cresol are both degradation products of $\beta$-carotene and along with $\beta$-carotene were identified as potential biomarkers for milk derived from pasture. The only correlation that appeared to influence the flavor of milk as determined using ranked descriptive analysis was p-cresol. P-Cresol appears to be responsible for the barnyard aroma of milk and is also likely derived from the deamination and decarboxylation of tryptophan and tyrosine due to the higher levels of available protein in the grass and grass/clover
\end{abstract}

Received May 10, 2017.

Accepted October 18, 2017.

${ }^{1}$ Corresponding author: kieran.kilcawley@teagasc.ie diets. The highest levels of p-cresol were in the grass/ clover diets and are likely due to the degradation of the isoflavone formononetin in the rumen, which is present in white clover swards.

Key words: milk, forage, sensory, volatile

\section{INTRODUCTION}

Products derived from cows grazing natural swards compared with those fed with preserved forages have added value among food producers and consumers because of their perceived healthiness and environmental acceptability. Bovine milk composition and flavor variations have been attributed to feed, seasonal variation, and breed (Bendall, 2001; Croissant et al., 2007; Larsen et al., 2013; Vanbergue et al., 2017). Badings and Neeter (1980) suggested that the aroma of milk is determined by many volatile compounds sometimes present in very low concentrations, some transferred from the feed, and others the result of minor conversions of milk constituents by chemical (oxidative or thermal), microbial, and enzymatic reactions. Volatile compounds in forage and feed enter milk through 2 routes: the main route is being absorbed in the digestive tract (i.e., rumen and or intestine) before diffusing into the blood and then reaching the mammary gland. The second route is the pulmonary route, where volatiles diffuse into the air and are inhaled by the cow, absorbed into the lungs, enter the blood stream, and subsequently diffuse into the mammary gland (Viallon et al., 2000). Conflicting results on the effect of different forage types on milk flavor exist. Using descriptive analysis, both Croissant et al. (2007) and Khanal et al. (2005) found significant differences in milk flavor based on diet (pasture vs. conventional TMR), but also found that differences were not perceived in consumer acceptance trials using untrained consumers. Shingfield et al. (2005) carried out descriptive sensory analysis and found that different silage and hay diets had no sensory effect on pasteurized bovine milk, whereas Moorby et al. (2009) 
also using descriptive sensory analysis found little effect on milk sensory properties based on dietary treatment (grass and red clover silages), except that boiled milk flavor increased significantly with the portion of red clover in the diet. Bertilsson and Murphy (2003) used difference testing with trained assessors and found that the sensory quality of milk differed between milks from cows fed perennial ryegrass and red and white clover silages and that the milk from red clover silages deviated more frequently from milk considered good quality milk.

Previous studies have highlighted that terpenes and carotenoids can potentially affect milk flavor directly as aromatic compounds or indirectly by acting as precursors to other volatile aromatic compounds (Martin et al., 2005; Villeneuve et al., 2013). Forage has also been shown to alter the fatty acid profile of milk and the protein content of milk (Croissant et al., 2007; Coppa et al., 2011; O'Callaghan et al., 2016b). The fatty acid composition of milk likely plays a direct role in flavor as short-chain free fatty acids $\left(\mathrm{C}_{4: 0}\right.$ to $\left.\mathrm{C}_{10: 0}\right)$ are volatile and aromatic (Kilcawley, 2017), but also increasing levels of unsaturation in fatty acids may increase the susceptibility of oxidation and thus milk from pasture is potentially more susceptible to oxidation, despite the presence of natural antioxidants in the milk (Havemose et al., 2006). Studies have shown that cows fed on a pasture diet received more protein than cows fed on a supplement (Bendall, 2001; Coppa et al., 2011). As the pasture diet has less energy, much of the protein is broken down so that the gluconeogenic AA are used as an energy source (Mackle et al., 1999). The metabolism of branched, aromatic, and sulfur AA by rumen bacteria can result in a wide range of odor active volatile compounds (aldehydes, acids, alcohols, ketones, and phenols) that can be potentially transferred to the mammary gland (Carlson and Breeze, 1984; Calvo and de la Hoz, 1992; Villeneuve et al., 2013; Jansson et al., 2014). Heat treatment can also alter the volatile profile of bovine milk, as, for example, it can promote the decarboxylation of $\beta$-keto acids to generate methyl ketones or lactones (Forss, 1979; Hougaard et al., 2011), the degradation of $\beta$-carotene (Zepka et al., 2014), the oxidation of methanethiol to a range of sulfur compounds (Contarini et al., 1997), or the generation of Maillard reaction products (Calvo and de la Hoz, 1992).

The aim of this study was to investigate the sensory quality and aromatic properties of bovine milk (raw and pasteurized) obtained from Friesian cows over a lactation on 3 distinct feeding regimens: outdoors on a perennial ryegrass pasture, outdoors on a perennial ryegrass/white clover pasture, and indoors on TMR. This study was carried out in conjunction with a recently published study, where the experiential design, trial details, milk composition, and total fatty acid contents of the milks are provided (O'Callaghan et al., 2016b).

\section{MATERIALS AND METHODS}

\section{Feed Samples}

The grass and grass clover samples were taken using a grass clippers cutting above the root and were collected from random areas that had been grazed to get a representative sample. Representative TMR samples were taken from a bulk supply. Grass samples were denoted as "grass," grass clover samples denoted as "grass/clover," and TMR samples as "TMR." Samples were taken at 3 different time points over a season, corresponding to the 3 milk collection times (early, mid, and late lactation).

\section{Milk Samples and Processing}

Raw milk was collected from the Teagasc Moorepark dairy farm (Fermoy, Co. Cork, Ireland) from the 3 different spring-calving herds as outlined in O'Callaghan et al. (2016b) at 3 different time points of lactation (early, mid, and late). All results are averages from samples and analysis undertaken at early, mid, and late lactation. Microbial analysis was performed immediately, pasteurization was performed within $20 \mathrm{~h}$, and sensory analysis within $24 \mathrm{~h}$. For the purpose of this study, the different milk types are denoted as $\mathbf{G}$ for grass, $\mathbf{C}$ for grass/clover, and TMR. Where necessary, the prefix $\mathbf{r}$ is used to denote raw milk and $\mathbf{p}$ to denote pasteurized milk.

Each milk sample was homogenized [GEA Niro Soavi S.p.A. Type: NS2006H (non-aseptic)] using 2-stage homogenization at 5,000 to $150,000 \mathrm{kPa}$. The milk was then pasteurized using a Microthermics (UHT/HTST Electric Model 25HV Hybrid, Liquid Technologies, Wexford, Ireland) unit heated to $72^{\circ} \mathrm{C}$ and held for $15 \mathrm{~s}$, then cooled to $4^{\circ} \mathrm{C}$. Each milk sample were transferred at $4^{\circ} \mathrm{C}$ to the sterile product outlet and aseptically packed into sterile 1-L glass bottles.

\section{Microbial Analyses}

The pour plate method was used to estimate the number of viable units of microorganisms per milliliter of raw and pasteurized milk samples (total bacteria count). Dilutions from $10^{0}$ to $10^{4}$ of the milk sample were mixed with maximum recover diluent (Oxoid CM0733, Waltham, MA). One milliliter of each dilution was pipetted onto sterile Petri dishes using the pour plate method and left to stand and subsequently incubated at $30^{\circ} \mathrm{C}$ for $72 \mathrm{~h}$. Following incubation, colonies 
that developed were counted and the number of microorganisms per milliliter of the original milk sample was calculated. Analysis was performed in triplicate.

\section{$\beta$-Carotene Analyses}

The $\beta$-carotene analyses were performed as described in O'Callaghan et al. (2016a).

\section{Milk Color Analyses}

Measurements were performed according to the CIE Lab system (CIE, 1978; L, CIE lightness coordinate; a, CIE red/green color attribute; b, CIE yellow/blue color attribute), using a Minolta colorimeter (Minolta Camera, Osaka, Japan). Samples were analyzed $30 \mathrm{~min}$ after the exposure to air to allow the stabilization of color. Results were expressed as the average of 5 replicate measurements on the different parts of the liquid milk samples and averaged over the season.

\section{Volatile Analyses}

Headspace Solid-Phase Micro Extraction of Raw and Pasteurized Milk and Feed Samples. Headspace solid-phase micro extraction (HS-SPME) analysis was performed as described in O'Callaghan et al. (2016a), except that $2 \mathrm{~g}$ of milk and $2 \mathrm{~g}$ of feed $(\mathrm{G}$, $\mathrm{C}$, and TMR) were used. All analyses were performed in triplicate.

Sorbtive Extraction of Pasteurized Milk Samples. A sorbtive extraction (SE) probe (Markes International Ltd., Llantrisant, UK) coated in polydimethylsiloxane, pre-conditioned for $1 \mathrm{~h}$ at $280^{\circ} \mathrm{C}$ under nitrogen, was inserted into $5 \mathrm{~mL}$ of milk in a $15 \% \mathrm{NaCl}$ (wt/ vol) solution in a $20-\mathrm{mL}$ amber headspace vial (Apex Scientific Ltd., Maynooth, Co. Kildare, Ireland). The vial was sealed with a screw-capped silicone/polytetrafluoroethylene liner magnetic cap and agitated for 1 $\mathrm{h}$ at $250 \mathrm{rpm}$ at $37^{\circ} \mathrm{C}$ in a HiSorb agitator (Markes International Ltd.). The extraction probe was removed from the sample mixture and rinsed with distilled water and dried with a lint-free cloth and inserted into an empty thermal desorption (TD) tube. This tube was placed in a Unity 2 TD unit (Markes International Ltd.) connected to an Agilent 7890A GC coupled with a 5977B single quadrupole MS (Agilent Technologies Ltd., Little Island, Cork, Ireland). The TD tube was initially pre-purged for 2 min using a $20 \mathrm{~mL} / \mathrm{min}$ split under helium. The tube was desorbed to a cold trap (material emissions) at $110^{\circ} \mathrm{C}$ for $0.5 \mathrm{~min}$ with a 10 $\mathrm{mL} / \mathrm{min}$ split, and then at $200^{\circ} \mathrm{C}$ for $10 \mathrm{~min}$ without a split. The cold trap temperature was maintained at $30^{\circ} \mathrm{C}$. The trap flow was set at $50 \mathrm{~mL} / \mathrm{min}$ and after a pre-trap fire purge of 2 min the trap was heated to $280^{\circ} \mathrm{C}$ at a rate of $100^{\circ} \mathrm{C} / \mathrm{s}$ and held for 5 min without a split (total split 10:1). The flow path temperature into the $\mathrm{GC}$ injector was set at $160^{\circ} \mathrm{C}$. A DB-5 MS $(60 \mathrm{~m}$ $\times 0.25 \mathrm{~mm} \times 0.25 \mu \mathrm{m})$ column (Agilent Technologies Ltd.) was used and the initial oven temperature was set at $35^{\circ} \mathrm{C}$, held for $0.5 \mathrm{~min}$, increased at $6.5^{\circ} \mathrm{C} / \mathrm{min}$ to $230^{\circ} \mathrm{C}$, then increased at $15^{\circ} \mathrm{C} / \mathrm{min}$ to $320^{\circ} \mathrm{C}$, yielding at total GC run time of $41.5 \mathrm{~min}$. The carrier gas was helium held at a constant pressure of $158.579 \mathrm{kPa}$. The ion source temperature was $230^{\circ} \mathrm{C}$ and the interface temperature was $280^{\circ} \mathrm{C}$ and the MS mode was electronic ionization $(70 \mathrm{v})$ with the mass range scanned between 35 and 250 amu. Compounds were identified using inhouse library created in Masshunter software (Agilent Technologies Ltd.) with target and qualifier ions and linear retention indices (Vandendool and Kratz, 1963) for each compound and from combinations of authentic standards, mass spectra comparisons to the NIST 2014 mass spectral library. An auto-tune of the GCMS was carried out before the analysis to ensure optimal GCMS performance. A set of external standards was run at the start and end of the sample set and abundances were compared with known amounts to ensure that both the SPME extraction and MS detection were performing within specifications. Analysis was performed in triplicate.

\section{Sensory Analyses}

Twenty-five naïve assessors were recruited in University College Cork, Ireland. Age range of assessors was 21 to 48 yr old. Selection criteria for assessors were availability and motivation to participate on all days of the experiment and that they were bovine milk consumers. Sensory acceptance testing was conducted as described in O'Callaghan et al. (2016a). The results presented were raw data assessed by 25 assessors each on different days at 3 separate time points (early, mid, and late lactation). Assessors used the sensory hedonic descriptors in Supplemental Table S1 (https://doi.org/ 10.3168/jds.2017-13141) for 3 different pasteurized milk samples (pG, pC, and pTMR). Twenty-five assessors then participated in ranking descriptive analysis (RDA; Richter et al., 2010) using the consensus list of sensory descriptors (Supplemental Table S1; https://doi .org/10.3168/jds.2017-13141), which was also measured on a $10-\mathrm{cm}$ line scale. All samples were a presented in duplicate (Stone et al., 2012) and the results are averages of samples assessed by 10 assessors taken at 3 separate time points (early, mid, and late lactation). 
Table 1. $\beta$-Carotene content $(\mathrm{mg} / \mathrm{kg})$ of the pasteurized $(\mathrm{p})$ milks [grass $(\mathrm{G})$, grass/clover $(\mathrm{C})$, and TMR] over the lactation season ${ }^{1}$

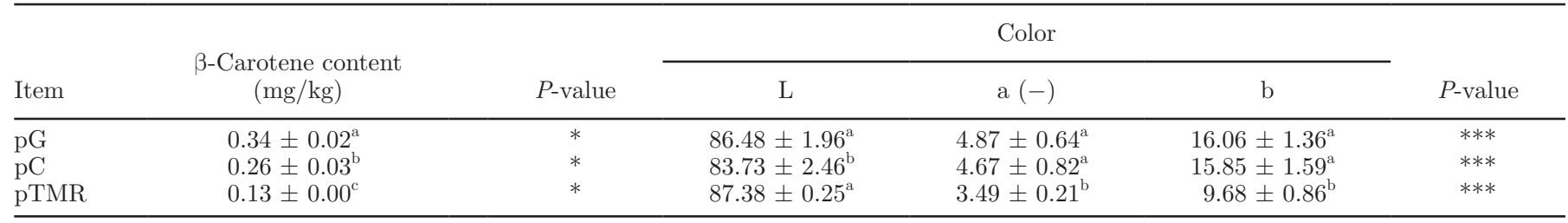

${ }^{\mathrm{a}-\mathrm{c}}$ Values within a column with different superscripts are statistically different at $P<0.05$.

${ }^{1}$ The color of pasteurized milk measurements were performed according to the Commission Internationale d'Eclairage $(\mathrm{CIE}) \mathrm{Lab}$ system $(\mathrm{L}=$ CIE lightness coordinate; $\mathrm{a}=\mathrm{CIE}$ red/green color attribute; $\mathrm{b}=\mathrm{CIE}$ yellow/blue color attribute) using a colorimeter.

One-way ANOVA statistical analysis: ${ }^{*} P \leq 0.05 ;{ }^{* * *} P \leq 0.001$.

\section{Statistical Analyses}

Statistical analyses for data relating to sensory evaluation and volatile analysis were carried out using ANOVA partial least squares regression. Mean data were calculated with standard error of the mean; significance was denoted at $P<0.05$. Analysis of variance partial least squares regression of sensory and volatile data was analyzed using the Unscrambler Software, version 10.3 (CAMO ASA, Trondheim, Norway). The $\mathrm{X}$ and $\mathrm{Y}$ matrix was designed so that $\mathrm{X}$ was the sample name(s) and $\mathrm{Y}$ was the volatile and sensory data. Close proximity of samples (G, C, and TMR) to sensory attributes and volatiles indicates correlation between the sample and the particular sensory attribute/volatile. The level of significance for correlation was set at $P<$ 0.05. Statistical analysis for $\beta$-carotene and milk color was performed using SPSS v18.0 (IBM Statistics Inc., Armonk, NY). Data sets were analyzed for normality using the Shapiro-Wilk test and for homogeneity of variance using Levene's test. Analyses were carried out at only one time point and where normally distributed were analyzed using one-way ANOVA with post hoc Tukey test.

\section{RESULTS}

\section{Milk Composition (Raw Milk)}

Compositional results are provided in O'Callaghan et al. (2016b), who found that the main difference was that 16 fatty acids varied significantly $(P<0.05)$ depending on feeding systems.

\section{Microbial Analyses (Raw and Pasteurized Milk)}

Total bacteria count was carried out on the raw and pasteurized milk samples from each feed type (Supplemental Table S2; https://doi.org/10.3168/jds.2017 -13141). As anticipated, a significant decrease $(P<$ 0.05 ) occurred in the microbial activity after pasteurization.

\section{$\beta$-Carotene (Pasteurized Milk)}

The pG milks had significantly $(P<0.05)$ higher levels of $\beta$-carotene in comparison to both the $\mathrm{pC}$ and pTMR milks (Table 1), in agreement with Croissant et al. (2007). The pTMR milk contained the lowest level of $\beta$-carotene $(0.13 \pm 0.0 \mathrm{mg} / \mathrm{kg})$. These concentrations are comparable with other studies (Shingfield et al., 2005; Havemose et al., 2006).

\section{Milk Color (Pasteurized Milk)}

The L (lightness), a (red/green color), and b (yellow/blue color) values were statistically different $(P<$ 0.001 ) between the samples (pG, pC, and pTMR; Table $1)$. The $\mathrm{b}$ value was statistically $(P<0.001)$ higher in $\mathrm{pG}$ and $\mathrm{pC}$ than in $\mathrm{pTMR}$. The a values were negative for all samples with a statistically $(P<0.001)$ higher value for $\mathrm{pTMR}$ than in $\mathrm{pG}$ and $\mathrm{pC}$. The $\mathrm{L}$ value was statistically $(P<0.05)$ higher in pTMR and pG than in $\mathrm{pC}$.

\section{Volatiles Analysis (Feed, Raw, and Pasteurized Milk)}

Feed Samples. Volatile analysis was carried out on the feed samples (grass, grass/clover, and TMR) by HS-SPME and were averaged for each stage of lactation. The TMR feed contained 65 volatile compounds, with the grass having 34 and the grass/clover having 49 (Table 2). Figure 1 is a pie chart showing the percentage of each chemical class identified within each feed type over lactation. It is apparent that the range of volatile chemical classes in both the grass and grass/clover feed samples were quite similar, but different to the TMR feed samples. The TMR feed samples contained more esters, acids, and phenols, and fewer ketones, aldehydes, furans, terpenes, and sulfur compounds. Thirteen esters, 6 alcohols, 6 ketones, 5 acids, 3 aldehydes, 2 phenols, 1 terpene, and 1 furan were significantly different between the feed types at $P<0.001$; and 5 alcohols, 4 esters, 4 ketones, 2 hydrocarbons, 1 acid, 1 terpene, 1 
Table 2. The volatile compounds, identified by headspace solid-phase micro extraction GC-MS analysis of the fed samples (grass, grass/clover, and TMR); values indicate area values for each compound

\begin{tabular}{|c|c|c|c|c|c|c|}
\hline Compound & CAS no. ${ }^{1}$ & $\operatorname{LRI}^{1}$ & Grass & Grass/clover & TMR & $P$-value \\
\hline \multicolumn{7}{|l|}{ Ester } \\
\hline Ethyl acetate & $141-78-6$ & 559 & $0.00 \mathrm{E}+00$ & $9.85 \mathrm{E}+05$ & $6.74 \mathrm{E}+07$ & *** \\
\hline Ethyl propionate & $105-37-3$ & 709 & $1.05 \mathrm{E}+05$ & $0.00 \mathrm{E}+00$ & $7.41 \mathrm{E}+06$ & *** \\
\hline Ethyl butanoate & $105-54-4$ & 800 & $2.08 \mathrm{E}+05$ & $3.58 \mathrm{E}+04$ & $1.75 \mathrm{E}+08$ & $* * *$ \\
\hline Methyl valerate & $624-24-8$ & 822 & $5.51 \mathrm{E}+03$ & $7.21 \mathrm{E}+04$ & $7.16 \mathrm{E}+06$ & NS \\
\hline Butyl acetate & $123-86-4$ & 812 & $0.00 \mathrm{E}+00$ & $0.00 \mathrm{E}+00$ & $8.90 \mathrm{E}+06$ & $* * *$ \\
\hline Pentyl acetate & $628-63-7$ & 911 & $0.00 \mathrm{E}+00$ & $0.00 \mathrm{E}+00$ & $1.16 \mathrm{E}+06$ & $* * *$ \\
\hline Ethyl pentanoate & $539-82-2$ & 898 & $7.20 \mathrm{E}+05$ & $0.00 \mathrm{E}+00$ & $5.79 \mathrm{E}+07$ & $* * *$ \\
\hline Methyl hexanoate & $106-70-7$ & 922 & $0.00 \mathrm{E}+00$ & $3.93 \mathrm{E}+06$ & $2.68 \mathrm{E}+07$ & $* * *$ \\
\hline Pentyl propionoate & $624-54-4$ & 967 & $0.00 \mathrm{E}+00$ & $0.00 \mathrm{E}+00$ & $7.77 \mathrm{E}+06$ & * \\
\hline Butyl butanoate & $109-21-7$ & 993 & $0.00 \mathrm{E}+00$ & $0.00 \mathrm{E}+00$ & $5.15 \mathrm{E}+07$ & * \\
\hline Ethyl hexanoate & $123-66-0$ & 996 & $2.59 \mathrm{E}+05$ & $0.00 \mathrm{E}+00$ & $5.94 \mathrm{E}+08$ & $* * *$ \\
\hline Butyl isovalerate & 109-19-3 & 1,044 & $0.00 \mathrm{E}+00$ & $0.00 \mathrm{E}+00$ & $8.74 \mathrm{E}+05$ & $*$ \\
\hline \multicolumn{7}{|l|}{ Alcohol } \\
\hline Ethanol & $64-17-5$ & $<500$ & $3.07 \mathrm{E}+07$ & $4.51 \mathrm{E}+06$ & $8.90 \mathrm{E}+07$ & NS \\
\hline 1-Butanol & $71-36-3$ & 599 & $0.00 \mathrm{E}+00$ & $0.00 \mathrm{E}+00$ & $6.99 \mathrm{E}+06$ & NS \\
\hline 2-Butanol R & 14898-79-4 & $<500$ & $0.00 \mathrm{E}+00$ & $0.00 \mathrm{E}+00$ & $2.21 \mathrm{E}+05$ & NS \\
\hline 1-Penten-3-ol & $616-25-1$ & 650 & $1.34 \mathrm{E}+07$ & $1.05 \mathrm{E}+07$ & $2.46 \mathrm{E}+05$ & $* * *$ \\
\hline 3-Methyl-1-butanol & $123-51-3$ & 733 & $6.24 \mathrm{E}+07$ & $4.86 \mathrm{E}+06$ & $3.39 \mathrm{E}+07$ & $*$ \\
\hline 2-Methyl-1-butanol & $1565-80-6$ & 737 & $1.60 \mathrm{E}+07$ & $1.13 \mathrm{E}+06$ & $1.01 \mathrm{E}+07$ & $* * *$ \\
\hline 1-Pentanol & $71-41-0$ & 764 & $5.07 \mathrm{E}+06$ & $5.05 \mathrm{E}+06$ & $8.80 \mathrm{E}+05$ & $*$ \\
\hline 2-Penten-1-ol, (Z)- & $1576-95-0$ & 766 & $2.01 \mathrm{E}+06$ & $3.59 \mathrm{E}+06$ & $0.00 \mathrm{E}+00$ & $* * *$ \\
\hline 2-Furanmethanol & $98-00-0$ & 862 & $4.24 \mathrm{E}+05$ & $8.43 \mathrm{E}+05$ & $3.89 \mathrm{E}+06$ & NS \\
\hline 2-Hexen-1-ol, (E)- & $928-95-0$ & 849 & $3.76 \mathrm{E}+05$ & $3.14 \mathrm{E}+07$ & $0.00 \mathrm{E}+00$ & $*$ \\
\hline 3-Hexen-1-ol, (Z)- & $928-96-1$ & 855 & $2.49 \mathrm{E}+07$ & $2.27 \mathrm{E}+07$ & $0.00 \mathrm{E}+00$ & $* * *$ \\
\hline 1-Hexanol & $111-27-3$ & 867 & $2.22 \mathrm{E}+07$ & $1.13 \mathrm{E}+08$ & $1.11 \mathrm{E}+07$ & * \\
\hline 1-Octen-3-ol & $3391-86-4$ & 978 & $1.75 \mathrm{E}+06$ & $1.29 \mathrm{E}+08$ & $1.38 \mathrm{E}+07$ & * \\
\hline 2-Hexanone & $591-78-6$ & 788 & $2.32 \mathrm{E}+04$ & $5.21 \mathrm{E}+04$ & $0.00 \mathrm{E}+00$ & $*$ \\
\hline 2-Heptanone & $110-43-0$ & 889 & $1.28 \mathrm{E}+06$ & $4.00 \mathrm{E}+05$ & $7.86 \mathrm{E}+06$ & $* * *$ \\
\hline 3-Octanone & $106-68-3$ & 984 & $5.58 \mathrm{E}+07$ & $5.90 \mathrm{E}+08$ & $1.36 \mathrm{E}+07$ & $* * *$ \\
\hline 8-Nonen-2-one & $5009-32-5$ & 1,121 & $1.74 \mathrm{E}+04$ & $0.00 \mathrm{E}+00$ & $0.00 \mathrm{E}+00$ & $* * *$ \\
\hline 2-Nonanone & $821-55-6$ & 1,131 & $8.26 \mathrm{E}+05$ & $1.64 \mathrm{E}+05$ & $0.00 \mathrm{E}+00$ & $*$ \\
\hline 2-Undecanone & $112-12-9$ & 1,289 & $1.83 \mathrm{E}+05$ & $2.37 \mathrm{E}+04$ & $8.40 \mathrm{E}+05$ & NS \\
\hline \multicolumn{7}{|l|}{ Aldehyde } \\
\hline 2-Methyl butanal & $96-17-3$ & 609 & $9.78 \mathrm{E}+04$ & $9.90 \mathrm{E}+04$ & $6.04 \mathrm{E}+06$ & NS \\
\hline Hexanal & $66-25-1$ & 801 & $0.00 \mathrm{E}+00$ & $5.42 \mathrm{E}+06$ & $0.00 \mathrm{E}+00$ & *** \\
\hline Heptanal & $111-71-7$ & 902 & $1.19 \mathrm{E}+04$ & $2.96 \mathrm{E}+06$ & $2.88 \mathrm{E}+05$ & NS \\
\hline Benzaldehyde & $100-52-7$ & 897 & $1.29 \mathrm{E}+06$ & $1.99 \mathrm{E}+06$ & $1.05 \mathrm{E}+07$ & NS \\
\hline Benzeneacetaldehyde & $122-78-1$ & 998 & $0.00 \mathrm{E}+00$ & $4.01 \mathrm{E}+05$ & $6.15 \mathrm{E}+06$ & $* * *$ \\
\hline Nonanal & $124-19-6$ & 1,100 & $6.75 \mathrm{E}+05$ & $1.59 \mathrm{E}+06$ & $5.62 \mathrm{E}+06$ & $* * *$ \\
\hline \multicolumn{7}{|l|}{ Acid } \\
\hline Acetic acid & $64-19-7$ & $<500$ & $8.54 \mathrm{E}+06$ & $3.79 \mathrm{E}+06$ & $1.63 \mathrm{E}+08$ & *** \\
\hline Butanoic acid & $107-92-6$ & 828 & $7.45 \mathrm{E}+04$ & $1.10 \mathrm{E}+04$ & $1.88 \mathrm{E}+07$ & $* * *$ \\
\hline 3-Methyl butanoic acid & $503-74-2$ & 858 & $3.62 \mathrm{E}+03$ & $0.00 \mathrm{E}+00$ & $1.44 \mathrm{E}+07$ & $* * *$ \\
\hline 2-Methyl butanoic acid & $116-53-0$ & 871 & $0.00 \mathrm{E}+00$ & $0.00 \mathrm{E}+00$ & $4.35 \mathrm{E}+06$ & $* * *$ \\
\hline Hexanoic acid & $142-62-1$ & 971 & $9.43 \mathrm{E}+05$ & $4.26 \mathrm{E}+06$ & $4.06 \mathrm{E}+07$ & $* * *$ \\
\hline Heptanoic acid & $503-74-2$ & 858 & $0.00 \mathrm{E}+00$ & $0.00 \mathrm{E}+00$ & $3.74 \mathrm{E}+06$ & $*$ \\
\hline 2-Methyl propanoic acid & $116-53-0$ & 871 & $0.00 \mathrm{E}+00$ & $0.00 \mathrm{E}+00$ & $4.76 \mathrm{E}+05$ & NS \\
\hline
\end{tabular}


Table 2 (Continued). The volatile compounds, identified by headspace solid-phase micro extraction GC-MS analysis of the fed samples (grass, grass/clover, and TMR); values indicate area values for each compound

\begin{tabular}{|c|c|c|c|c|c|c|}
\hline Compound & CAS no. ${ }^{1}$ & $\mathrm{LRI}^{1}$ & Grass & Grass/clover & TMR & $P$-value \\
\hline Toluene & $108-88-3$ & 768 & $3.19 \mathrm{E}+05$ & $5.01 \mathrm{E}+04$ & $4.38 \mathrm{E}+05$ & NS \\
\hline Ethylbenzene & $100-41-4$ & 864 & $5.23 \mathrm{E}+05$ & $0.00 \mathrm{E}+00$ & $1.82 \mathrm{E}+06$ & * \\
\hline p-Xylene & $106-42-3$ & 897 & $3.28 \mathrm{E}+05$ & $2.87 \mathrm{E}+04$ & $2.77 \mathrm{E}+04$ & NS \\
\hline Benzene, 1,3-bis (1,1-dimethyl) & $1014-60-4$ & 1,251 & $1.02 \mathrm{E}+06$ & $0.00 \mathrm{E}+00$ & $1.57 \mathrm{E}+06$ & * \\
\hline \multicolumn{7}{|l|}{ Phenolic } \\
\hline Creosol (4-methylguaiacol) & $93-51-6$ & 1,192 & $0.00 \mathrm{E}+00$ & $0.00 \mathrm{E}+00$ & $6.40 \mathrm{E}+05$ & $* * *$ \\
\hline \multicolumn{7}{|l|}{ Terpene } \\
\hline L- $\alpha$-Terpineol & $98-55-5$ & 1,002 & $1.80 \mathrm{E}+04$ & $0.00 \mathrm{E}+00$ & $4.60 \mathrm{E}+05$ & $* * *$ \\
\hline$\beta$-Myrcene & $123-35-3$ & 988 & $1.26 \mathrm{E}+05$ & $1.54 \mathrm{E}+04$ & $0.00 \mathrm{E}+00$ & $*$ \\
\hline Z- $\beta$-Ocimene & $3338-55-4$ & 1,035 & $7.68 \mathrm{E}+06$ & $3.76 \mathrm{E}+05$ & $0.00 \mathrm{E}+00$ & NS \\
\hline trans- $\beta$-Ocimene & 3779-61-1 & 1,046 & $3.93 \mathrm{E}+06$ & $1.90 \mathrm{E}+05$ & $0.00 \mathrm{E}+00$ & NS \\
\hline \multicolumn{7}{|l|}{ Furan } \\
\hline
\end{tabular}

${ }^{1}$ CAS no. $=$ Chemical Abstracts Service number. LRI $=$ linear retention index.

One-way ANOVA statistical analysis: ${ }^{*} P<0.05$ and ${ }^{* * *} P<0.001$.

furan, and 1 sulfur compound were significantly different between the feed types at $P<0.05$.

Volatiles in Raw Milk. The volatiles in the raw milk samples were also analyzed by HS-SPME. In total, 40 volatile compounds were identified in the $\mathrm{rG}, \mathrm{rC}$, and rTMR milk samples (Table 3). Twenty-two volatile compounds identified in the feed samples were also found in the raw milk samples. Only 12 volatiles were present in each feed type and in each raw milk (acetic acid, butanoic acid, hexanoic acid, heptanal, nonanal, acetone, 2-heptanone, 1-pentanol, 1-octen-3-ol, toluene, $\mathrm{m}$-xylene, and p-xylene). Thirteen volatile compounds were found in all raw milk samples (octanoic acid, nonanoic acid, n-decanoic acid, 2-ethyl-hexanoic acid, pentanal, 3-methyl butanal, decanal, methyl isobutyl ketone, ethyl benzene, ethyl ether, dimethyl sulfide, dimethyl sulfone, and $\beta$-pinene), but were not present in the corresponding feed samples. In addition some other compounds were present in some specific feeds but not in the associated milks (1-octanol, hexanal, and 2-nonanone). Only 6 of the 40 volatile compounds detected in the raw milk samples were statistically $(P$ $<0.001$ ) different (Table 2) based on diet (acetic acid, hexanal, 2-butanone, 1-pentanol, dimethyl sulfone, and toluene). Acetic acid, 1-pentanol, and toluene were highest in the $\mathrm{rG}$ milks and lowest in the rTMR milks.

Volatiles in Pasteurized Milk. The pasteurized milk samples were also analyzed by HS-SPME using the same extraction and chromatography conditions. Thirty-six volatile compounds were identified in the pasteurized milk samples (pG, pC, and pTMR) and
32 (Table 3) were common to the raw milk samples. However, only 21 compounds were present in each raw and corresponding pasteurized milk sample. Some compounds present in the raw milk samples were not present in their corresponding pasteurized milk samples, suggesting alteration by heat treatment. Only 1-octen3-ol was present in all the raw milk samples, but absent in all the pasteurized milk samples; other volatiles (benzaldehyde, 2-methyl-butanal, 2-ethyl-hexanoic acid, butanoic acid, butyl acetate, 1-hexanol, 1-octanol 3 -methyl-butanol, $\beta$-pinene, and 2-pentyl furan) were also absent, but only for some pasteurized milk feed types. Other compounds were present in pasteurized milks but absent in the raw milks (n-decanoic acid, 2-methyl butanal, benzeneacetaldehyde, 2-nonanone, butyl acetate, ethyl ether, 3-octanone, o-xylene, 1-octanol, and $\gamma$-butrolactone). Statistical differences based on diet were evident; pentanal, heptanal, 1-pentanol, dimethyl sulfone, $\gamma$-butyrolactone, toluene, and $\beta$-pinene at $P<0.001$ and benzeneacetaldehyde, 2-butanone, and methyl isobutyl ketone at $P<0.05$ (Table 3). Figure 2 is a partial least squares regression plot of the average volatiles over a season in the raw and pasteurized milk samples as determined by HS-SPME. This plot highlights differences the volatile profile between the raw milks ( $\mathrm{rG}, \mathrm{rC}$, and $\mathrm{rTMR}$ ) very effectively, but also highlights the effect of pasteurization, as both the $\mathrm{rG}$ and $\mathrm{rC}$ milks are clearly separated from the $\mathrm{pG}$ and pC milks. It is apparent from Figure 2 that in relation to the volatiles deemed statistically different by partial least squares regression (1-pentanol, toluene, dimethyl 
sulfone, and 2-butanone) some observations can be made. The association of 1-pentanol is greater with the $\mathrm{pC}$ and $\mathrm{pG}$ milks than the $\mathrm{rC}$ and $\mathrm{rG}$ milks, and that dimethyl sulfone has a greater association with the $\mathrm{rG}$ and $\mathrm{rC}$ than the $\mathrm{pG}$ and $\mathrm{pC}$ milks. Also, 2-butanone has a greater association with rTMR than with pTMR, highlighting direct effects of pasteurization on these volatile compounds.

We also investigated the volatiles in the pasteurized milk samples using an alternate extraction technique, SE. The SE technique uses polydimethylsiloxane as an absorbent and is more applicable in general to less polar compounds and has significantly greater absorbent capacity than a SPME fiber. In addition, we included a salting out stage to aid recovery of polar compounds. The selectivity of both extraction techniques was quite different. The SE technique identified 38 volatiles in the pasteurized milk samples (Table 4), where the HSSPME technique identified 36, and only 14 volatiles were common to both extraction techniques. Additional aldehydes, ketones, lactones, alcohols, furans, esters, a hydrocarbon, and a terpene were identified using the SE technique. Most volatiles identified using SE were present in all the pasteurized milk samples.

\section{Sensory Analysis (Pasteurized Milk)}

The use of sensory acceptance testing in conjunction with RDA facilitated the analysis of the samples and replication, and these rapid sensory methods provided a general sensory observable trend. Figure 3 highlights the hedonic sensory analysis of pasteurized milks over lactation. pG milk scored higher for every attribute, but was statistically $(P<0.05)$ highest for "overall acceptability," "liking of texture," and "liking of flavor." The $\mathrm{pC}$ milk scored lowest for all attributes except for "liking of texture," but only differed statistically $(P$ $<0.05)$ to the pTMR milk for "liking of flavor" and "overall acceptability." The panel consisted of Irish consumers of milk, who would be most familiar with milk produced from grass-fed milk and therefore this result may not be that surprising. Incorporation of larger numbers of panelists including members more familiar with milk derived from pTMR may provide alternate results. Supplemental Figure S1 (https://doi.org/10 .3168/jds.2017-13141) represents a radar plot of the average ranked descriptive sensory analysis of the $\mathrm{pG}$, $\mathrm{pC}$, and pTMR milks over lactation. Distinct differences were evident between each milk based on forage type, with "color," "barnyard aroma," and "viscosity" significantly $(P<0.05)$ different between the samples averaged over lactation. The pG milk scored highest for "color" and "viscosity" and pC milk for "barnyard aroma." It would be interesting to compare results of the RDA used in this study with quantitative descriptive sensory analysis to determine if greater differences could be observed.

\section{DISCUSSION}

O'Callaghan et al. (2016b) found some differences in the composition of milks from each of the diets in this study. A main difference was that 16 fatty acids varied significantly $(P<0.05)$ depending on feeding systems. Polyunsaturated fatty acids were significantly higher $(P$ $<0.05)$ in $\mathrm{rG}$ and $\mathrm{rC}$ milks than rTMR milks; however, some potentially important differences existed that may affect oxidative rancidity. In relation to the PUFA present at the greatest concentrations, linoleic acid was significantly higher in rTMR milks than in rG or $\mathrm{rC}$ milks and linoleic acid and CLA were significantly higher in $\mathrm{rG}$ and $\mathrm{rC}$ than in rTMR milks, palmitic acid was significantly $(P<0.05)$ higher in $\mathrm{rTMR}$ than in $\mathrm{rG}$ or $\mathrm{rC}$ milks, and no statistical difference was evident between the rG, rC, and rTMR milks for oleic acid (O'Callaghan et al., 2016b).

Twenty-two volatile compounds were identified in the feed and in the raw milk samples, with 12 volatiles present in each feed type and in each raw milk (acetic acid, butanoic acid, hexanoic acid, heptanal, nonanal, acetone, 2-heptanone, 1-pentanol, 1-octen-3-ol, toluene, $\mathrm{m}$-xylene, and p-xylene). It is possible that at least some of these compounds were transferred directly from the feed to the raw milk either by the pulmonary or digestive route, as highlighted by Contarini et al. (1997) and Valero et al. (2001). However, Bugaud et al. (2001a) stated that it is difficult to get correlations between nonterpene volatiles in the feed and in the subsequent milk because of the metabolic activity of microbial populations in the rumen and in the milk. Losses of volatiles may also occur due to excretion or due to accumulation in other tissues (Bertilsson and Murphy, 2003). Contarini et al. (1997) highlighted that acetone can originate directly from feed. It is well established that toluene is a product of $\beta$-carotene degradation in the rumen (Villeneuve et al., 2013). Acetic acid is primarily a product of carbohydrate metabolism (Kilcawley, 2017); with both butanoic and hexanoic acids synthesized de novo by the mammary gland, the presence of free fatty acids in milk is due to incomplete esterification in the mammary gland before lipid creation or lipolysis in the milk during storage (Villeneuve et al., 2013; O'Callaghan et al., 2016b). Heptanal and nonanal are primary products, and 2-heptanone, 1-pentanol, 1-octen-3-ol are secondary products of lipid oxidation (or also possibly $\beta$-ketoacid decarboxylation in the case of 2-heptanone; Calvo and de la Hoz, 1992; Moio et al., 1993; Valero et al., 2001; 


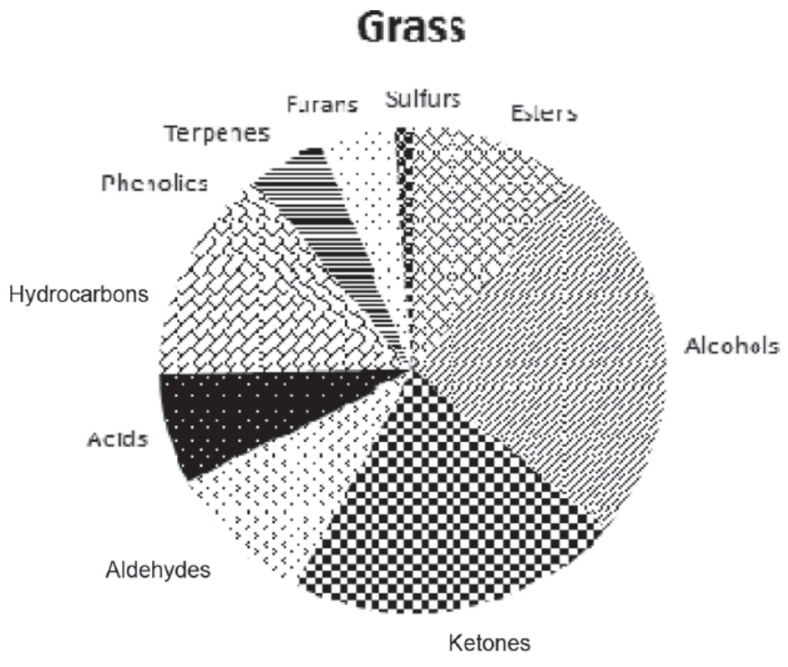

\section{Grass/Clover}

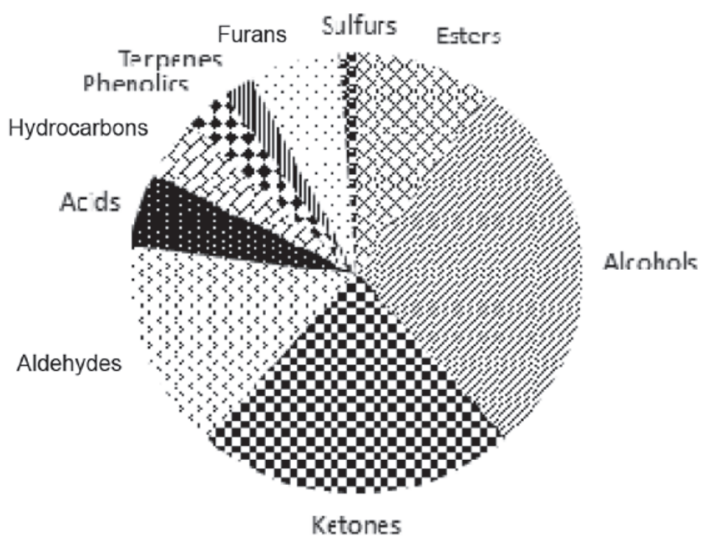

TMR

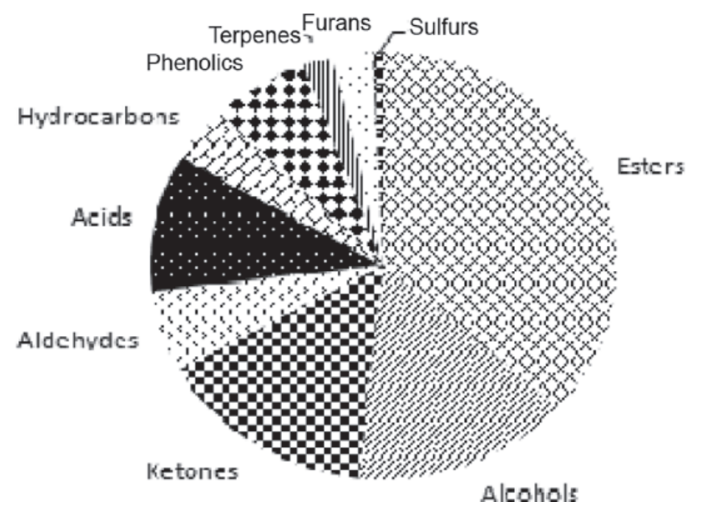

Figure 1. Pie charts showing the percentage of different chemical classes (esters, alcohols, ketones, aldehydes, acids, alcohols, aldehydes, phenols, hydrocarbons, furans, terpenes, and sulfur compounds) identified within each feed type (grass, grass/clover, and TMR) over the whole lactation season.
Vazquez-Landaverde et al., 2005). Both m-xylene and p-xylene may be the result of carotenoid degradation, namely $\beta$-carotene degradation in the rumen (Zepka et al., 2014) or possibly directly transferred from feed (Buchin et al., 1998). Other volatiles were present in the feed and corresponding raw milk samples, but only for specific samples. In general, herbage-based diets have a higher protein to readily digestible carbohydrate ratio, and thus contain more volatiles from AA metabolism (Mackle et al., 1999; Coppa et al., 2011) because the pasture diet has less energy. The metabolism of branched, aromatic, and sulfur AA by rumen bacterial can result in a wide range of odor active volatile compounds (aldehydes, acids, alcohols, ketones, and phenols) that can be potentially transferred to the mammary gland (Carlson and Breeze, 1984; Calvo and de la Hoz, 1992; Villeneuve et al., 2013; Jansson et al., 2014). The TMR feed contained a large amount of esters presumably due to the presence of alcohols derived from carbohydrate fermentation and short-chain free fatty acids, and thus butyl acetate may have been transferred directly from the feed due to its absence in the other feeds and milks. Some volatiles were present in some specific feeds but not in the associated raw milks, suggesting that these compounds were likely produced either in the rumen or in the milk, or concentrated in the milk.

Only 6 of the 40 volatile compounds detected in the raw milk samples were statistically $(P<0.001)$ different based on diet (acetic acid, hexanal, 2-butanone, 1-pentanol, dimethyl sulfone, and toluene). Acetic acid, 1-pentanol, and toluene were highest in the $\mathrm{rG}$ milks and lowest in the rTMR milks. As previously stated, acetic acid is primarily a product of carbohydrate metabolism (Kilcawley, 2017). Levels were highest in $\mathrm{rG}$ and $\mathrm{rC}$ milks, yet levels of lactose were similar in all milks (O'Callaghan et al., 2016b) and acetic acid levels were highest in the TMR feed. However, acetic acid can also be produced from the metabolism of AA (Ganesan and Weimer, 2007) and this may also be a factor due to the higher levels of available protein in the milks from grass and grass/clover. Acetic acid is also utilized in the biosynthesis of $\beta$-ketoacids in the mammary gland (Mottram et al., 1996) and this may also account for some of the differences in these milks. 1-Pentanol is derived from reduction of pentanal (Villeneuve et al., 2013), which is derived from the oxidation of arachidonic acid (C20:4 n-6; Romeu-Nadal et al., 2004), which was highest pG and pC milk (O'Callaghan et al., 2016b). Toluene was highest in $\mathrm{rG}$ and $\mathrm{rC}$ milks and derived from $\beta$-carotene, which was also higher in $\mathrm{pG}$ and $\mathrm{pC}$ milks. It is well established that $\beta$-carotene is at higher levels in fresh than in conserved forage (Croissant et al., 2007; Coppa et al., 2011). Hexanal and 2-butanone were highest in the rTMR milks and lowest in rG milks. 
Table 3. Relationship between cow feeding regimen [grass $(\mathrm{G})$, grass/clover $(\mathrm{C})$, and TMR] and the raw $(\mathrm{r})$ and pasteurized (p) milk volatile compounds, identified by headspace solid-phase micro extraction GC-MS analysis; values indicate area values for each compound

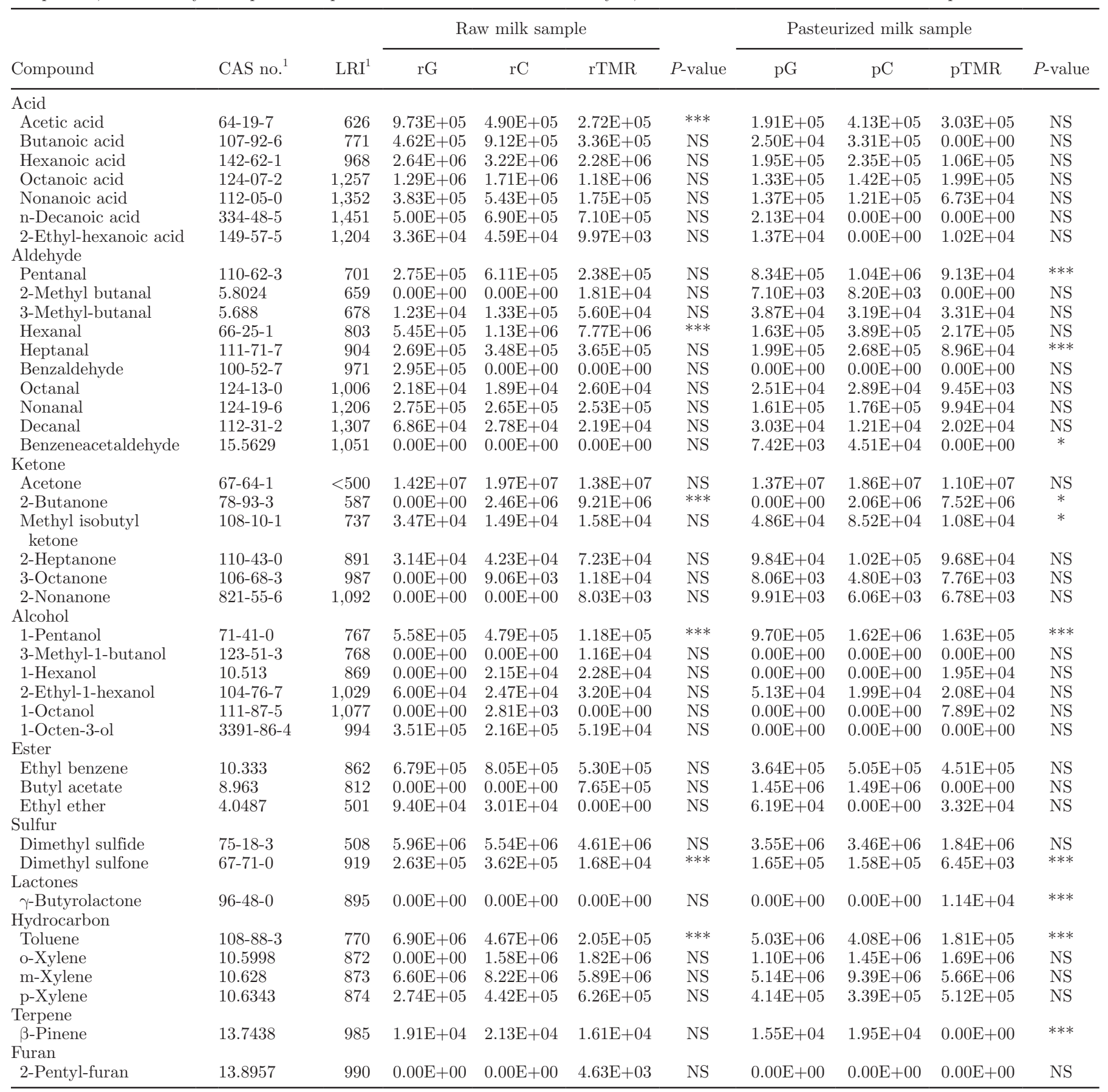

${ }^{1}$ CAS no. $=$ Chemical Abstracts Service number. LRI $=$ linear retention index.

One-way ANOVA statistical analysis: ${ }^{*} P<0.05$ and ${ }^{* * *} P<0.001$.

Hexanal is a primary product of lipid oxidation and mostly associated with the degradation of oleic and linoleic acid (Vazquez-Landaverde et al., 2005), and thus higher levels can be directly related to higher levels of linoleic acid in the rTMR milk (O'Callaghan et al., 2016b). 2-Butanone is thought to be transferred di- rectly from the feed (Valero et al., 2001), as levels were higher in the grass/clover feed than in the TMR feed; however, metabolism of carbohydrate in the rumen or milk is also likely a factor.

Some compounds present in the raw milk samples were not present in their corresponding pasteurized 
milk samples, suggesting losses or changes due to heat treatment. However, metabolic and enzymatic reactions that occur during raw milk storage before pasteurization may also be responsible for losses of compounds after pasteurization (Calvo and de la Hoz, 1992; Contarini et al., 1997). Other compounds were present in pasteurized milks but absent in the raw milks and it is well established that certain volatiles can increase in milk after heat treatment, for example, ketones and lactones (Calvo and de la Hoz, 1992). Lactones are formed from thermal breakdown of $\delta$ - and $\gamma$-hydroxyacids (Dimick et al., 1969). Products of Strecker degradation (Contarini et al., 1997), sulfur compounds (Vazquez-Landaverde et al., 2005), degradation of $\beta$-carotene to toluene, xylenes, and other compounds are all thought to increase after heat treatment (Zepka et al., 2014). It has been suggested that some esters, such as ethyl acetate, are formed by heat-catalyzed esterification reactions (Vazquez Landaverde et al., 2005). Forss (1979) also suggested the autoxidation of SFA is promoted by heat treatment. Obviously the degree and extent of heating governs product formation, but it appears the activation energy required may not need to be that high.

As stated, statistical differences based on diet were also evident (pentanal, heptanal, 1-pentanol, dimethyl sulfone, $\gamma$-butyrolactone, toluene, and $\beta$-pinene at $P<$ 0.001 and benzeneacetaldehyde, 2 -butanone, and methyl isobutyl ketone at $P<0.05)$ in the pasteurized milks as determined by HS-SPME (Table 3). Pentanal, heptanal, and 1-pentanol are all products of lipid oxidation and were higher in $\mathrm{pG}$ and $\mathrm{pC}$ than in pTMR milks, which follows the same trends for raw milk based on fatty acid content. Methyl isobutyl ketone is also likely a product of lipid oxidation but was not present in raw milk. Toluene also follows the same trend for raw milk. Dimethyl sulfone is a product of methionine degradation (Vazquez-Landaverde et al., 2005; Villeneuve et al., 2013) and may be higher in $\mathrm{pG}$ and $\mathrm{pC}$ than pTMR milks due to higher concentrations of more digestible proteins, in agreement with other studies (Toso et al.,

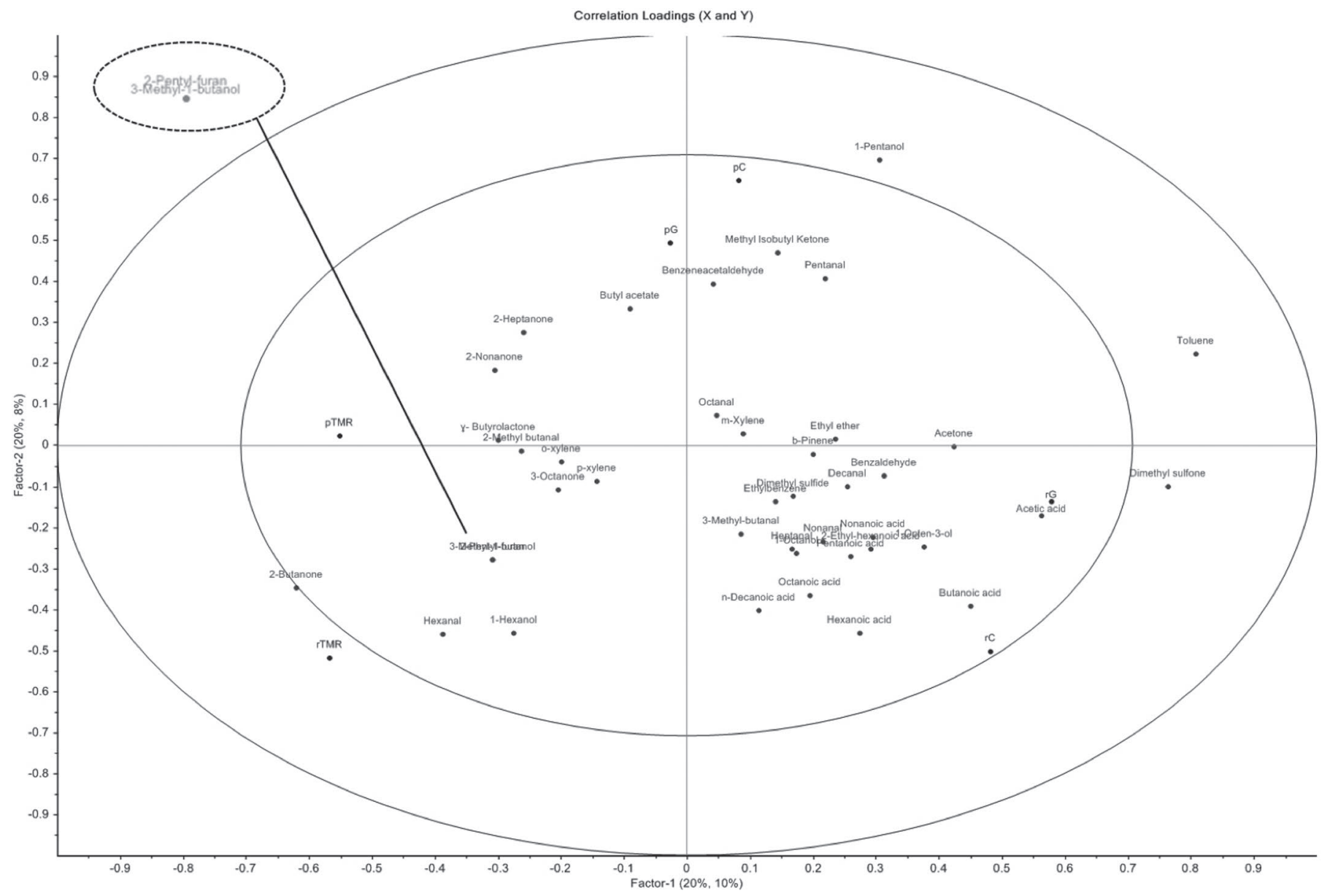

Figure 2. Multivariate data analysis partial least squares regression plot of headspace solid-phase micro extraction results for raw and pasteurized milk samples of different feeding systems (grass, grass/clover, and TMR) over the lactation season. The different milk types are denoted as $\mathrm{G}$ for grass, $\mathrm{C}$ for grass/clover, and TMR. The prefix $\mathrm{r}$ is used to denote raw milk and $\mathrm{p}$ to denote pasteurized milk. 
Table 4. Relationship between cow feeding regimen [grass $(\mathrm{G})$, grass/clover $(\mathrm{C})$, and $\mathrm{TMR}$ ] and the pasteurized milk (p) volatile compounds, identified by sorbtive extraction GC-MS analysis; values indicate area values for each compound

\begin{tabular}{|c|c|c|c|c|c|c|}
\hline Target compound & CAS no. ${ }^{1}$ & $\mathrm{LRI}^{1}$ & $\mathrm{pG}$ & $\mathrm{pC}$ & pTMR & $P$-value \\
\hline \multicolumn{7}{|l|}{ Acid } \\
\hline Acetic acid & $64-19-7$ & 592 & $2.79 \mathrm{E}+07$ & $2.64 \mathrm{E}+07$ & $4.03 \mathrm{E}+07$ & NS \\
\hline Octanoic acid & $124-07-2$ & 1,163 & $1.30 \mathrm{E}+07$ & $7.50 \mathrm{E}+06$ & $9.72 \mathrm{E}+06$ & NS \\
\hline Nonanoic acid & $112-05-0$ & 1,259 & $9.08 \mathrm{E}+06$ & $7.60 \mathrm{E}+06$ & $8.84 \mathrm{E}+06$ & NS \\
\hline n-Decanoic acid & $334-48-5$ & 1,360 & $7.62 \mathrm{E}+07$ & $7.76 \mathrm{E}+07$ & $6.92 \mathrm{E}+07$ & NS \\
\hline Hexanal & $66-25-1$ & 800 & $2.50 \mathrm{E}+06$ & $2.19 \mathrm{E}+06$ & $3.60 \mathrm{E}+06$ & NS \\
\hline Heptanal & $111-71-7$ & 902 & $1.80 \mathrm{E}+06$ & $1.66 \mathrm{E}+06$ & $1.87 \mathrm{E}+06$ & NS \\
\hline Octanal & $124-13-0$ & 1,003 & $2.69 \mathrm{E}+06$ & $2.90 \mathrm{E}+06$ & $3.19 \mathrm{E}+06$ & NS \\
\hline Nonanal & $124-19-6$ & 1,104 & $1.57 \mathrm{E}+07$ & $1.62 \mathrm{E}+07$ & $1.82 \mathrm{E}+07$ & NS \\
\hline 2-Nonenal, (E)- & $18829-56-6$ & 1,161 & $6.74 \mathrm{E}+05$ & $1.48 \mathrm{E}+05$ & $3.89 \mathrm{E}+05$ & NS \\
\hline Decanal & $112-31-2$ & 1,206 & $6.28 \mathrm{E}+06$ & $8.78 \mathrm{E}+06$ & $7.39 \mathrm{E}+06$ & NS \\
\hline 2-Decenal, (Z)- & $2497-25-8$ & 1,264 & $7.23 \mathrm{E}+05$ & $4.04 \mathrm{E}+05$ & $1.03 \mathrm{E}+06$ & NS \\
\hline 5-Hydroxymethylfurfural & $67-47-0$ & 1,224 & $1.53 \mathrm{E}+07$ & $1.45 \mathrm{E}+07$ & $2.76 \mathrm{E}+07$ & NS \\
\hline 2-Furanmethanol & $98-00-0$ & 850 & $1.28 \mathrm{E}+08$ & $1.45 \mathrm{E}+08$ & $2.37 \mathrm{E}+08$ & $*$ \\
\hline 5-Methyl-2-furanmethanol & $3857-25-8$ & 949 & $4.17 \mathrm{E}+05$ & $3.64 \mathrm{E}+05$ & $2.14 \mathrm{E}+05$ & NS \\
\hline \multicolumn{7}{|l|}{ Ketone } \\
\hline 2-Heptanone & $110-43-0$ & 888 & $3.05 \mathrm{E}+05$ & $2.25 \mathrm{E}+05$ & $7.73 \mathrm{E}+04$ & NS \\
\hline Acetophenone & $98-86-2$ & 1,071 & $9.65 \mathrm{E}+05$ & $1.31 \mathrm{E}+06$ & $1.24 \mathrm{E}+06$ & NS \\
\hline 2-Pentadecanone & $2345-28-0$ & 1,698 & $2.48 \mathrm{E}+06$ & $2.26 \mathrm{E}+06$ & $1.95 \mathrm{E}+06$ & NS \\
\hline \multicolumn{7}{|l|}{ Lactone } \\
\hline$\gamma$-Crotonolactone & $497-23-4$ & 909 & $5.04 \mathrm{E}+06$ & $5.39 \mathrm{E}+06$ & $7.66 \mathrm{E}+06$ & NS \\
\hline$\sigma$-Valerolactone (isomer) & $542-28-9$ & 1,055 & $1.26 \mathrm{E}+06$ & $1.45 \mathrm{E}+06$ & $3.14 \mathrm{E}+05$ & NS \\
\hline$\sigma$-Decalactone & $705-86-2$ & 1,501 & $3.71 \mathrm{E}+06$ & $4.84 \mathrm{E}+06$ & $5.01 \mathrm{E}+06$ & NS \\
\hline$\sigma$-Dodecalactone & $713-95-1$ & 1,719 & $3.90 \mathrm{E}+06$ & $4.66 \mathrm{E}+06$ & $4.67 \mathrm{E}+06$ & NS \\
\hline \multicolumn{7}{|l|}{ Alcohol } \\
\hline Isomaltol & $3420-59-5$ & 979 & $1.77 \mathrm{E}+06$ & $7.49 \mathrm{E}+05$ & $2.53 \mathrm{E}+06$ & NS \\
\hline p-Cresol & $106-44-5$ & 1,070 & $7.54 \mathrm{E}+05$ & $8.75 \mathrm{E}+05$ & $2.03 \mathrm{E}+05$ & $* * *$ \\
\hline \multicolumn{7}{|l|}{ Terpene } \\
\hline Squalene & $111-02-4$ & $<2,000$ & $3.54 \mathrm{E}+07$ & $2.94 \mathrm{E}+07$ & $2.96 \mathrm{E}+07$ & NS \\
\hline
\end{tabular}

${ }^{1}$ CAS no. $=$ Chemical Abstracts Service number. LRI $=$ linear retention index.

One-way ANOVA statistical analysis: ${ }^{*} P<0.05$ and ${ }^{* * *} P<0.001$.

2002; Coppa et al., 2011). Benzeneacetaldehyde is also product of protein metabolism, thus higher levels in $\mathrm{pG}$ and $\mathrm{pC}$ may also be due to degradation in the rumen (Kilcawley, 2017). 2-Butanone also follows the same trends as the raw milk. $\beta$-Pinene is most likely derived directly from forage, but concentrations are quite low in $\mathrm{pG}$ and $\mathrm{pC}$ and absent in pTMR. $\gamma$-Butyrolactone is likely formed from hydroxy acids during pasteurization.

The SE extraction identified different volatiles due to differences in the selectivity of the techniques used. Most volatiles identified using SE were present in all the pasteurized milk samples. Only hexanoic acid and 2-undecanal were present in $\mathrm{pG}$ and pTMR milks, but absent in $\mathrm{pC}$ milks, and dodecanal was absent in $\mathrm{pG}$ milk but present in pC and pTMR milks. Three compounds, 1-hexadecanol, 1-octadecanol, and p-cresol, were significantly different based on forage type $(P$ $<0.001)$. Both alcohols were at highest levels in the pG milks and lowest in pTMR milks, whereas p-cresol was highest in the pC milks and lowest in the pTMR milks. The alcohols are likely products of secondary lipid oxidation (Bugaud et al., 2001b), but p-cresol 


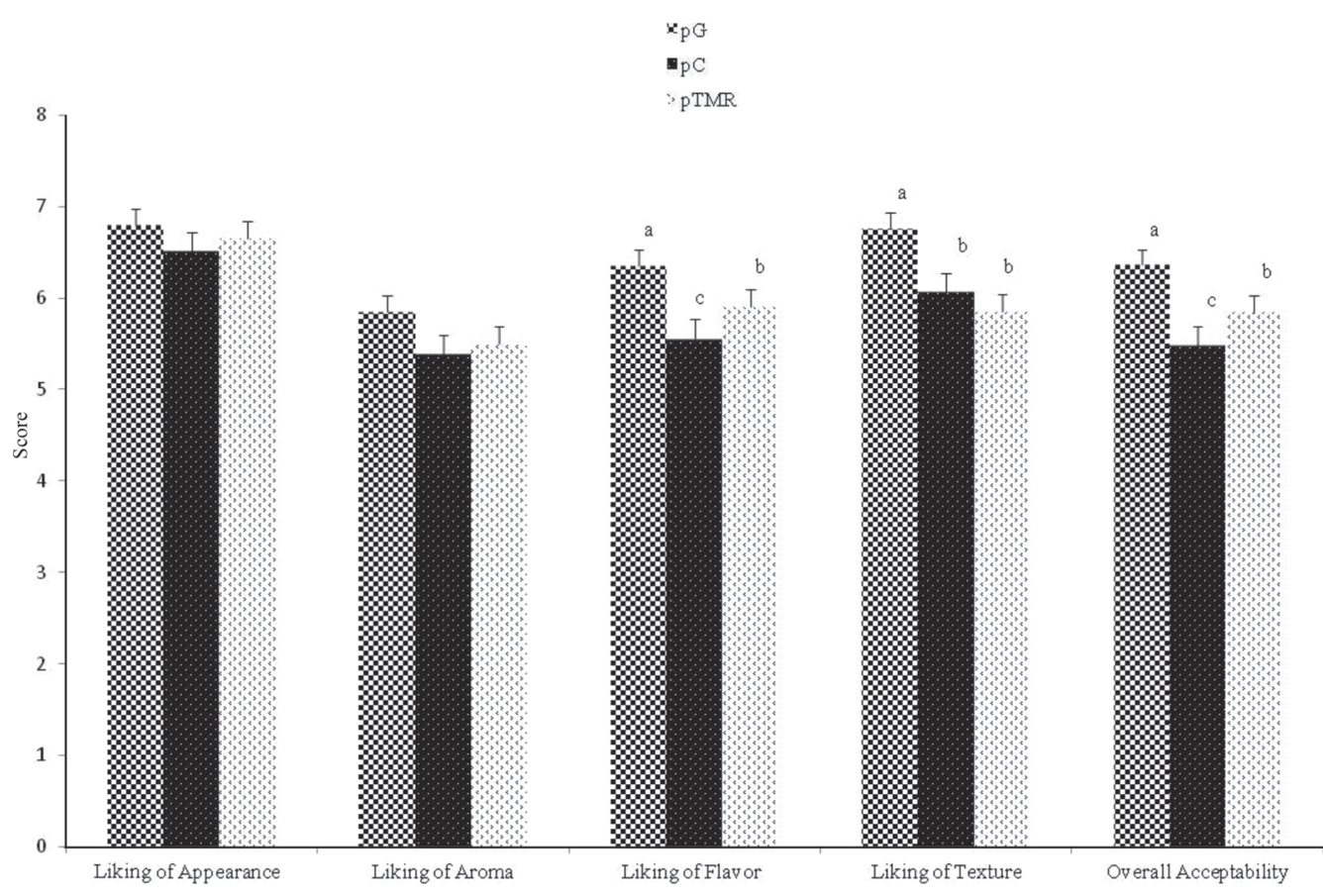

Figure 3. Hedonic sensory analysis of pasteurized milk derived from different feeding systems of grass (G), grass/clover (C), and TMR (p denotes pasteurized milk). The 3 milk samples were assessed by naïve Irish assessors $(\mathrm{n}=25)$ familiar with milk using blind replicates in a full balanced block design, where assessors evaluated all samples in duplicate. Results expressed are averages of milk from early, mid, and late lactation; thus, 150 repetitions/sensory observations were made for each product. The error bars represent standard mean error within replicates. Columns with different letters $(\mathrm{a}-\mathrm{c})$ for each attribute are statistically different $(P<0.05)$.

can be formed from a range of different sources. As the protein content is higher in pasture than in TMR, deamination and decarboxylation of AA are thought to occur to a greater extent in the rumen of cows fed pasture (Mackle et al., 1999; Coppa et al., 2011), and it has been established that phenolic compounds such as p-cresol result from the degradation of tryptophan and tyrosine (Carlson and Breeze, 1984). However, pcresol may also be produced from the degradation of $\beta$-carotene by a series of cyclization and oxidation reactions (Ueno et al., 2004). The higher levels in pC milks are likely due to the degradation of formononetin, an isoflavone that primarily occurs in leguminous plants such as clover (Zepka et al., 2014; Kilic and Lindsay, 2005). Five volatile compounds were significantly different based on forage at $(P<0.05$; butanoic acid, pentanal, hydroxy-2(5)H-furanone, 2-furanmethanol, and 1-phenylethanol). Butanoic acid, hydroxy-2(5)Hfuranone, and 2-furanmethanol were highest in pTMR milks and lowest in pG milks. Bugaud et al. (2001b) highlighted that furans in dairy products maybe a result of Maillard reactions between an AA and a sugar, or from oxidation of PUFA, thus levels may be higher in pTMR milks due to more available carbohydrate in the TMR feed or linked to differences in the fatty acid profile of the milk. Butanoic acid levels were higher in TMR feed, but not high or identified by HS-SPME in rTMR or pTMR milks, although this could be due to limitations of SPME (mainly fiber divinylbenzene/ carboxen/polydimethylsiloxane) analysis for very polar compounds. As mentioned, butanoic acid is also synthesized de nova by the mammary gland, which may be influenced by the feed (Yayota et al., 2013). Pentanal was highest in pG and lowest in pTMR milks and this correlates well with HS-SPME data and the fatty acid content of the milks. 1-Phenylethanol was highest in $\mathrm{pC}$ milks and lowest in pTMR milks and is a product of the metabolism of the aromatic AA phenylalanine (Lee and Richard, 1984) and thus may be higher in the pC and pG milks due to the greater protein content (Mackle et al., 1999; Coppa et al., 2011).

In terms of sensory analysis, "color," "barnyard aroma," and "viscosity" were significantly $(P<0.05)$ different based on forage as determined by RDA. The difference in "color" is correlated with $\beta$-carotene content and $\mathrm{b}$ value, which corresponds to yellow/blue attribute. Martin et al. (2005) summarized that dairy products produced from pasture have a higher yellow intensity. It is difficult to discern a direct link between "viscosity" and the different forage milk samples, although it may be associated with differences in the fatty acid content of the pG milk to the other pasteurized milks. 
Palmitic and oleic acids are the principal saturated and unsaturated fatty acids in dairy products with high and low melting points, respectively. The ratio of oleic acid to palmitic acid has previously been used as an index of hardness in butter and cheese (Martin et al., 2005). In this case the ratio of oleic to palmitic acid is lower in $\mathrm{pG}$ and highest in pTMR milks (O'Callaghan et al., 2016b). Barnyard aroma or flavor has been associated with p-cresol in dairy products (Moio et al., 1993; Kilic and Lindsay, 2005), and Khanal et al. (2005) associated barnyard flavor in milk with cows grazing on pasture. The major alkylphenol present in ruminant milk is pcresol; although numerous potential sources of p-cresol exist, it seems most likely that a direct link between pcresol levels in $\mathrm{rC}$ milk as detected by $\mathrm{SE}$ and barnyard aroma exists due to the degradation of the isoflavone formononetin in white clover (Kilic and Lindsay, 2005).

\section{CONCLUSIONS}

Pasteurization altered the volatile profile of all milks, with losses of some compounds and the development or augmentation of others. Sensory assessors preferred pasteurized milk produced from grass-fed cows, and had the least preference for milk produced from cows fed TMR over the season. This may be due to the fact that the assessors were Irish and thus used to milk derived from grass fed cows. Tentative associations between feed and some nonterpene volatiles appear to highlight a potential direct transfer to milk. Little or no evidence existed in relation to the transfer of terpenes from feed to milk, possibly due in part to the nature of the forage used in the trials. Some products of lipid oxidation were evident and were likely related to fatty acid content as influenced by forage type. However, none of these affected the sensory perception of milk as determined by RDA. Other differences in volatiles based on diet appear to relate to the protein/carbohydrate availability and subsequent digestion in the rumen. $\beta$-Carotene appears to have directly influenced perceived milk color with higher levels in milk derived from grass and grass/clover. Degradation of $\beta$-carotene in the rumen to toluene and in part to p-cresol was likely responsible for higher levels of these volatiles in milk from grass and grass/ clover and could be used with $\beta$-carotene as potential biomarkers for milk derived from pasture. Higher levels of p-cresol in $\mathrm{pC}$ and $\mathrm{pG}$ milks are also likely due to the metabolism of aromatic AA in the rumen; however, the highest levels in $\mathrm{pC}$ are very likely due to the degradation of an isoflavone found in white clover also in the rumen. p-Cresol appears to have directly affected the sensory properties of milk as it is most likely the source of barnyard aroma in these milks.

\section{ACKNOWLEDGMENTS}

This work was funded by the Department of Agriculture, Fisheries and Food, under the Food Institutional Research Measure; Sensory Network Ireland Reference 13SN401. The authors sincerely thank David Mannion (Teagasc) for his support in gas chromatography-mass spectrometry analysis of the volatile compounds and Gareth Roberts (Markes International Ltd.) for use of the HiSorb sorbtive extraction system, and the technical and farm staff at Moorepark for their excellent care of the experimental cows and assistance during the experiment. Ethical approval statement: Teagasc has both an animal welfare body (AWB) and animal ethics committee. The AWB is a legal requirement of Article 26 of Directive 2010/63/EU and Regulation 50 of S.I. No. 543 of 2012. The Health Products Regulatory Authority (HPRA) provides project authorization, and the HPRA License number for this project is AE19132/ P019. The authors declare no conflict of interest.

\section{REFERENCES}

Badings, H., and R. Neeter. 1980. Recent advances in the study of aroma compounds of milk and dairy products. Neth. Milk Dairy J. 34:9-30.

Bendall, J. G. 2001. Aroma compounds of fresh milk from New Zealand cows fed different diets. J. Agric. Food Chem. 49:4825-4832.

Bertilsson, J., and M. Murphy. 2003. Effects of feeding clover silages on feed intake, milk production and digestion in dairy cows. Grass Forage Sci. 58:309-322. https://doi.org/10.1046/j.1365-2494.2003 .00383.x.

Buchin, S., V. Delague, G. Duboz, J. L. Berdague, E. Beuvier, S. Pochet, and R. Grappin. 1998. Influence of pasteurization and fat composition of milk on the volatile compounds and flavor characteristics of a semi-hard cheese. J. Dairy Sci. 81:3097-3108.

Bugaud, C., S. Buchin, J. B. Coulon, A. Hauwuy, and D. Dupont. 2001a. Influence of the nature of alpine pastures on plasmin activity, fatty acid and volatile compound composition of milk. Lait 81:401-414.

Bugaud, C., S. Buchin, A. Hauwuy, and J. B. Coulon. 2001b. Relationships between flavour and chemical composition of Abondance cheese derived from different types of pastures. Lait 81:757-773.

Calvo, M. M., and L. de la Hoz. 1992. Flavour of heated milks. A review. Int. Dairy J. 2:69-81. https://doi.org/10.1016/0958 $-6946(92) 90001-3$.

Carlson, J. R., and R. G. Breeze. 1984. Ruminal metabolism of plant toxins with emphasis on indolic compounds. J. Anim. Sci. 58:1040-1049.

CIE (Commission Internationale de l'Éclairage). 1978. Recommendations on Uniform Color Spaces, Color Difference Equations, Psychometric Color Terms. Supplement No. 2 to CIE Publication No. 15. Colorimetry, Bureau Central de la CIE, Paris, France.

Contarini, G., M. Povolo, R. Leardi, and P. M. Toppino. 1997. Influence of heat treatment on the volatile compounds of milk. J. Agric. Food Chem. 45:3171-3177. https://doi.org/10.1021/jf960849s.

Coppa, M., B. Martin, P. Pradel, B. Leotta, A. Priolo, and V. Vasta. 2011. Effect of a hay-based diet or different upland grazing systems on milk volatile compounds. J. Agric. Food Chem. 59:4947-4954. https://doi.org/10.1021/jf2005782.

Croissant, A. E., S. P. Washburn, L. L. Dean, and M. A. Drake. 2007. Chemical properties and consumer perception of fluid milk from conventional and pasture-based production systems. J. Dairy Sci. 90:4942-4953. https://doi.org/10.3168/jds.2007-0456. 
Dimick, P. S., N. J. Walker, and S. Patton. 1969. Occurrence and biochemical origin of aliphatic lactones in milk fat. J. Agric. Food Chem. 17:649-655.

Forss, D. A. 1979. Mechanisms of formation of aroma compounds in milk and milk products. J. Dairy Res. 46:691-706.

Ganesan, B., and B. C. Weimer. 2007. Amino acid metabolism in relationship to cheese flavor development. Pages 70-101 in Improving the Flavour of Cheese. B. C. Weimer, ed. Woodhead Publishing, Cambridge, UK.

Havemose, M. S., M. R. Weisbjerg, W. L. Bredie, H. D. Poulsen, and J. H. Nielsen. 2006. Oxidative stability of milk influenced by fatty acids, antioxidants, and copper derived from feed. J. Dairy Sci. 89:1970-1980. https://doi.org/10.3168/jds.S0022-0302(06)72264 -0 .

Hougaard, A. B., J. S. Vestergaard, C. Varming, W. L. P. Bredie, and R. H. Ipsen. 2011. Composition of volatile compounds in bovine milk heat treated by instant infusion pasteurisation and their correlation to sensory analysis. Int. J. Dairy Technol. 64:34-44. https://doi.org/10.1111/j.1471-0307.2010.00641.x.

Jansson, T. S. Jensen, N. Eggers, M. R. Clausen, L. B. Larsen, C. Ray, A. Sundgren, H. J. Andersen, and H. C. Bertram. 2014. Volatile component profiles of conventional and lactose-hydrolyzed UHT milk-a dynamic headspace gas chromatography-mass spectrometry study. Dairy Sci. Technol. 94:311-325. https://doi.org/ 10.1007/s13594-014-0164-7.

Khanal, R. C., T. R. Dhiman, A. L. Ure, C. P. Brennand, R. L. Boman, and D. J. McMahon. 2005. Consumer acceptability of conjugated linoleic acid-enriched milk and cheddar cheese from cows grazing on pasture. J. Dairy Sci. 88:1837-1847. https://doi.org/10 .3168/jds.S0022-0302(05)72858-7.

Kilcawley, K. N. 2017. Cheese flavour. Pages 443-474 in Fundamentals of Cheese Science. P. F. Fox, T. P. Guinee, T. M. Cogan, and P. L. H. McSweeney, ed. Springer, USA.

Kilic, M., and R. Lindsay. 2005. Distribution of conjugates of alkylphenols in milk from different ruminant species. J. Dairy Sci. 88:7-12. https://doi.org/10.3168/jds.S0022-0302(05)72656-4.

Larsen, M. K., U. Kidmose, T. Kristensen, P. Beaumont, and G. Mortensen. 2013. Chemical composition and sensory quality of bovine milk as affected by type of forage and proportion of concentrate in the feed ration. J. Sci. Food Agric. 93:93-99. https:// doi.org/10.1002/jsfa.5735.

Lee, C.-W., and J. Richard. 1984. Catabolism of L-phenylalanine by some microorganisms of cheese origin. J. Dairy Res. 51:461-469.

Mackle, T., D. Dwyer, and D. Bauman. 1999. Effects of branchedchain amino acids and sodium caseinate on milk protein concentration and yield from dairy cows. J. Dairy Sci. 82:161-171.

Martin, B., I. Verdier-Metz, S. Buchin, C. Hurtaud, and J.-B. Coulon. 2005. How do the nature of forages and pasture diversity influence the sensory quality of dairy livestock products? Anim. Sci 81:205-212.

Moio, L., J. Dekimpe, P. Etievant, and F. Addeo. 1993. Neutral volatile compounds in the raw milks from different species. J. Dairy Res. 60:199-213.

Moorby, J. M., M. R. Lee, D. R. Davies, E. J. Kim, G. R. Nute, N. M. Ellis, and N. D. Scollan. 2009. Assessment of dietary ratios of red clover and grass silages on milk production and milk quality in dairy cows. J. Dairy Sci. 92:1148-1160. https://doi.org/10.3168/ jds.2008-1771.

Mottram, D. S., I. C. Nobrega, A. T. Dodson, and J. S. Elmore. 1996. Changes in thiol and disulfide flavour compounds resulting from the interaction with proteins. Spec. Publ. R. Soc. Chem. 197:413418.

O'Callaghan, T. F., H. Faulkner, S. McAuliffe, M. G. O'Sullivan, D. Hennessy, P. Dillon, K. N. Kilcawley, C. Stanton, and R. P. Ross. 2016a. Quality characteristics, chemical composition, and sensory properties of butter from cows on pasture versus indoor feeding systems. J. Dairy Sci. 99:9441-9460. https://doi.org/10.3168/jds .2016-11271.

O'Callaghan, T. F., D. Hennessy, S. McAuliffe, K. N. Kilcawley, M. O'Donovan, P. Dillon, R. P. Ross, and C. Stanton. 2016b. Effect of pasture versus indoor feeding systems on raw milk composition and quality over an entire lactation. J. Dairy Sci. 99:9424-9440. https://doi.org/10.3168/jds.2016-10985.

Richter, V. B., T. C. A. de Almeida, S. H. Prodencio, and M. D. Benassi. 2010. Proposing a ranking descriptive sensory method Food Qual. Prefer. 21:611-620. https://doi.org/10.1016/j.foodqual .2010.03.011

Romeu-Nadal, M., A. Castellote, and M. López-Sabater. 2004. Headspace gas chromatographic method for determining volatile compounds in infant formulas. J. Chromatogr. A 1046:235-239.

Shingfield, K. J., P. Salo-Vaananen, E. Pahkala, V. Toivonen, S. Jaakkola, V. Piironen, and P. Huhtanen. 2005. Effect of forage conservation method, concentrate level and propylene glycol on the fatty acid composition and vitamin content of cows' milk. J. Dairy Res. 72:349-361. https://doi.org/10.1017/S0022029905000919.

Stone, H., R. Bleibaum, and H. Thomas. 2012. Test strategy and design of experiments. Pages 117-157 in Sensory Evaluation Practices. H. Stone, R. N. Bleibaum, and H. A. Thomas, ed. Elsevier Academic Press, USA.

Toso, B., G. Procida, and B. Stefanon. 2002. Determination of volatile compounds in cow's milk using headspace GC-MS. J. Dairy Res. 69:569-577.

Ueno, T., H. Masuda, and C. T. Ho. 2004. Formation mechanism of p-methylacetophenone from citral via a tert-alkoxy radical intermediate. J. Agric. Food Chem. 52:5677-5684. https://doi.org/10 $.1021 / \mathrm{jf035517j}$.

Valero, E., M. Villamiel, B. Miralles, J. Sanz, and I. Martinez-Castro. 2001. Changes in flavour and volatile components during storage of whole and skimmed UHT milk. Food Chem. 72:51-58. https:// doi.org/10.1016/S0308-8146(00)00203-X.

Vandendool, H., and P. D. Kratz. 1963. A generalization of the retention index system including linear temperature programmed gas-liquid partition chromatography. J. Chromatogr. 11:463-471.

Vanbergue, E., L. Delaby, J. L. Peyraud, S. Colette, Y. Gallard, and C. Hurtaud. 2017. Effects of breed, feeding system, and lactation stage on milk fat characteristics and spontaneous lipolysis in dairy cows. J. Dairy Sci. 100:4623-4636. https://doi.org/10.3168/ jds.2016-12094.

Vazquez-Landaverde, P. A., G. Velazquez, J. A. Torres, and M. C. Qian. 2005. Quantitative determination of thermally derived offflavor compounds in milk using solid-phase microextraction and gas chromatography. J. Dairy Sci. 88:3764-3772.

Viallon, C., B. Martin, I. Verdier-Metz, P. Pradel, J.-P. Garel, J.-B. Coulon, and J.-L. Berdagué. 2000. Transfer of monoterpenes and sesquiterpenes from forages into milk fat. Lait 80:635-641.

Villeneuve, M. P., Y. Lebeuf, R. Gervais, G. F. Tremblay, J. C. Vuillemard, J. Fortin, and P. Y. Chouinard. 2013. Milk volatile organic compounds and fatty acid profile in cows fed timothy as hay, pasture, or silage. J. Dairy Sci. 96:7181-7194. https://doi.org/10 $.3168 /$ jds.2013-6785.

Yayota, M., M. Tsukamoto, Y. Yamada, and S. Ohtani. 2013. Milk composition and flavor under different feeding systems: A survey of dairy farms. J. Dairy Sci. 96:5174-5183. https://doi.org/10 .3168/jds.2012-5963.

Zepka, L. Q., D. S. Garruti, K. L. Sampaio, A. Z. Mercadante, and M. A. A. P. Da Silva. 2014. Aroma compounds derived from the thermal degradation of carotenoids in a cashew apple juice model. Food Res. Int. 56:108-114. https://doi.org/10.1016/j.foodres.2013 .12 .015 . 